\title{
The Virtual Advantage: A review of the efforts to alter the rules of collection of state sales and use taxes from out-of-state e-tailers.
}

\author{
Brian Winrow ${ }^{1 *}$, Allen Richardson ${ }^{2}$ \\ ${ }^{1}$ Department of Accounting, Winona State University, Minnesota, United States \\ ${ }^{2}$ Department of Marketing, Winona State University, Minnesota, United States
}

\begin{abstract}
States have been prohibited from requiring out-of-state e-retailers who lack a physical presence in the state from being able to collect and remit state sales or use taxes on revenue generated from in-state purchases. The physical presence requirement has provided e-tailers with a competitive advantage in terms of price as compared to residential businesses. Since 2004, total annual online sales in North America have increased by $\$ 318$ billion, resulting in annual sales of $\$ 400$ billion, with worldwide online sales exceeding \$1 trillion annually. While retailers are unable to mandate collection of sales or use taxes on e-tailers without a physical presence within the state, consumers are required to report the taxes on their returns; however, it is estimated that only four percent of residents voluntarily report these taxes. As such, experts have calculated that states lose more than $\$ 12$ billion per year in lost sales and use tax. In 2018, however, the Supreme Court of the United States will be hearing a case challenging the current prohibition and plethora of precedence, to determine whether a state should be able to impose the burden to collect state sales taxes on outof-state e-tailers who lack a physical presence with the state in which the consumer purchased the item. Additionally, Congress continues to consider legislative action to afford states the power to mandate collection of sales taxes on nonresident sellers who lack a physical presence within the state. The possible changes relating to state's sales tax collection will alter e-tailers pricing strategies, minimizing the feasibility of the cost leadership approach. The purpose of this article is to analyze the genesis of cases relating to the collection of state sales taxes as well as recent congressional efforts to amend the current law and to describe how the changes will impact the ability of e-tailers to pursue a price leadership strategy. This research is important for two central reasons. First, extant research has not explored states sales tax differences in terms of Porter's pricing strategies. Secondly, the regulatory landscape is positioned to change, meaning existing practitioners will need to reevaluate their current strategies in order to adapt to the new regulatory environment.
\end{abstract}

Keywords: Sales tax, Use tax, E-tailers, Commerce clause, Pricing strategy.

\section{Introduction}

Over the past decade, sales derived from e-commerce have experienced an exponential rate of growth. The emergence of e-commerce has become a mainstay in everyday business transactions. The momentum of online commerce is particularly evident during holiday seasons where it has become integrated as a staple of commerce. The advantage of e-commerce frequently includes lower-prices based on market competition, as well as expanding the products available for consumers. According to e-marketer [1], annual internet sales exceeded $\$ 400$ billion in North America and one trillion dollars worldwide. In addition, $66 \%$ of consumers had made at least one online purchase [2]. In terms of customers, there were 167 million in 2012 [1], increasing to 224 million in 2016 [3]. Sales are predicted to increase to $\$ 632$ billion in 2020.
While e-commerce has permitted businesses to easily engage in transactions across the globe, the prohibition against requiring businesses without a physical presence in the state from collecting and remitting sales taxes for transactions within the state could be construed to yield a disparate impact in favor of e-tailers. When a consumer purchases a product from an out-of-state retailer, the consumer remains liable for the reporting and paying the state sales tax. The mere restriction of requiring states from imposing the duty on out-of-state sellers to collect state or sales use taxes does not excuse the consumer from reporting and paying sales taxes based on these purchases. Unfortunately, the prohibition on mandating the collection of state sales and use taxes support has resulted in significant loss revenue, with states such as California, experiencing a collection rate of about four percent on out-of-state purchases [4]. 
Since residential businesses are required to collect taxes at the point of sale, it provides an inaccurate perception that out-of-state e-tailers are the low-cost leaders as they can offer products at an immediately lower-price than residential businesses. The savings, however, are merely the deferred payment of state sales or use taxes, which should be voluntarily disclosed by the buyer. The perception of a lower-priced product directly impacts the business strategy of both residential businesses and e-tailers. Based on the current regulatory environment, the competitive environment for e-commerce in the retailing sector is conducive to a cost leadership strategy, as e-commerce advancements reflect the concept of a perfect market [5]. The utilization of the online format has stimulated price competition while reducing barriers on entry. Due to the lower transactional costs, many e-tailers have pursued a cost leadership strategy [5]. The cost leadership strategy is popular as e-tailers often possess significantly reduced transactional costs as compared to a brick-and-mortar business [6]. Consumer price sensitivity in e-commerce may be partially attributable to the reduction in search costs [7].

While the regulatory landscape has provided businesses with an environment conducive to the pursuit of a cost leadership strategy, both the U.S. Supreme Court and U.S. Congress have signaled their possible willingness to reconsider the current prohibition on requiring out-of-state businesses without a physical presence within the state to collect and remit state sales taxes. The purpose of this article is to analyze the genesis of cases relating to the collection of state sales taxes as well as recent congressional efforts to amend the current law and to describe how the changes will impact the ability of e-tailers to pursue a price leadership strategy. This research is important for two central reasons. First, extant research has not explored state sales tax differences in terms of Porter's pricing strategies. Secondly, the regulatory landscape is positioned to change, meaning existing practitioners will need to reevaluate their current strategies to adapt to the new regulatory environment. The article will commence with a literature review including a brief description of Porter's generic pricing strategies and the relationship between E-commerce and state taxation. The literature review will then discuss the National Bellas Hess v.Illinois case, and subsequent efforts to overrule the holding. The article will then briefly address the legislative efforts as it relates to the dormant commerce clause and burdens on interstate commerce. The article will conclude with an analysis as to how the changes with respect to imposition of state income taxes can impact e-tailers.

\section{Literature review}

In the seminal work on pricing strategies, Porter articulated three broad strategies that could be implemented to attain a competitive advantage within the industry [8]. Porter further provided that the failure to pursue one of the three pricing strategies would result in a company being "stuck in the middle", yielding unfavorable results. As advanced by Porter, the three classifications include cost leadership, differentiation, and focus [8]. When a firm implements a cost leadership strategy as a means to attain a sustainable competitive advantage, a cost minimization mindset must permeate throughout the business.

Under a cost leadership strategy, the organization must seek to implement cost-control measures. As stated by Allen and Helms, "A low-cost or cost leadership strategy is effectively implemented when the business designs, produces, and markets a comparable product more efficiently than its competitors" [9]. While much of the previous literature regarding the cost leadership strategy has centered on cost control mechanisms, there is evidence that the perception of a lower price based upon the seller's failure to collect state taxes could also yield a cost leadership position. The issue of state taxation is for business practitioners are complicated as there are over 9,000 different taxing agencies, which includes state, county, and cities [10]. Moreover, the lack of uniformity magnifies the complexity of state and local taxation as each of these taxing agencies have their own rates and regulations that the practitioner must comply with [10]. According to the Tax Foundation, as of January, 2018 there were 45 states plus the District of Columbia that imposed a state-level sales tax. In addition, 38 states have local sales taxes. The state with the highest combined state and local sales taxes was Louisiana which was slightly above 10 percent.

Previous research has explored the price sensitivity of consumers to state sales taxes. In a study conducted by Einay, Levin, and Sundaresan, it was concluded that for each percentage increase in state sales taxes, there was a decrease of approximately two percent as it relates to interest in the purchasing the product from that online consumer [11]. The study further concluded that intrastate purchases have a corresponding decrease as sales taxes increase [11]. More specifically, the sound found that a one-percent increase in state sales taxes yields a three percent to six percent decrease in interest by in state consumers. The relationship between increases sales taxes with decreases in interested consumers has been supported by other studies. In a study conducted by Goolsbee, the issue was framed differently, looking at the possible reduction in online purchases if existing state sales taxes were applied to online transactions [12]. In that study it was determined that enforcement of current tax laws could reduce online buyers by up to 24 percent. A study conducted by Alm and Melnik found that an increase in sales taxes decreases the probability of online purchases [13]. The study, however, found a much smaller relationship concluding that a one percent increase in taxes would decrease the probability of online purchases by 0.5 percent.

\section{Judicial Precedence}

One of the leading cases relating to the power of a state to impose a collection duty of state sales taxes on out-ofstate sellers was National Bellas Hess v. Illinois [14]. Bellas 
Hess operated a mail order business whereby it sold products across the nation. Bellas Hess maintained its principal place of business in Missouri and did not have property, sales outlets, employees, and did not advertise in the State of Illinois. Its only connection with the state was derived from the shipping of catalogues and merchandise subsequently purchased from those catalogs. The catalogues and merchandise were shipped via United States Postal Service. Based upon its minimal connection, Bellas Hess did not collect state sales taxes based upon its transactions in Illinois. The State of Illinois sought to require Bellas Hess to collect and remit sales taxes. The U.S Supreme Court held that the Commerce Clause excludes a State from requiring out-of-state sellers, whose only connection with customers in the State is by common carrier or by mail, from imposing a collection duty on the seller. The Commerce Clause disallows states actions that unduly inhibit interstate commerce.

Quill v. North Dakota: A second preeminent case barring states from imposing a duty on out-of-state e-tailers without a physical presence within the state is Quill v. North Dakota [15]. Quill Inc. was a Delaware corporation engaged in interstate commerce by selling office supplies and equipment through mail orders. The sales were solicited on a national level through catalogs and advertisements in periodicals as well as through unsolicited phone calls. In 1987, Quill's annual sales surpassed \$200,000,000, with roughly $\$ 1,000,000$ coming from sales to approximately 3,000 residents in North Dakota. The sales in North Dakota made it are the sixth largest vendor of office supplies in the State. While Quill was a Delaware corporation, it had offices and warehouses in Illinois, California, and Georgia, which served to facilitate its distribution of products. Quill did not have a physical location in North Dakota. Sales to customers were fulfilled by mail or common carrier originating from out-of-state locations.

Under North Dakota's tax code, only sellers with a place of business in North Dakota were required to collect use taxes on its sales. In 1987 North Dakota changed the statutory requirements requiring "every person who engages in regular or systematic solicitation of a consumer market in th[e] state" to collect use taxes, thus allowing the state to better collect on purchases from out-of-state vendors [16]. The regulations defined "regular or systematic solicitation" to include three or more advertisements within a 12-month period [16]. The result has been to require organizations, such as Quill, to collect sales or use taxes even though the seller lacks a physical presence in the state [15].

Quill filed suit contesting North Dakota's authority to require out-of-state vendors to collect taxes from state residents. The trial court held in favor of Quill finding the case indistinguishable from their previous holdings. On appeal, the North Dakota Supreme Court cited "wholesale changes" in the economy due to the emergence of mail-order retailers as well as recent developments in case law as the central basis to overturn the trial court [15]. More specifically, the Court held that North Dakota created "an economic climate that fosters demand for" Quill's products, maintained a legal infrastructure that protected that market, and disposed of 24 tons of catalogs and flyers mailed by Quill into the State every year. As a result, the North Dakota Supreme Court concluded that Quill maintained an "economic presence" in North Dakota based upon services and benefits provided by the State and therefore generated "a constitutionally sufficient nexus to justify imposition of the purely administrative duty of collecting and remitting the use tax" [15].

The U.S. Supreme Court granted certiorari. The issue presented before the U.S. Supreme Court was whether a seller must have a physical presence within the state to be subject to requirements to collect state or use taxes. The U.S. Supreme Court reversed the North Dakota Supreme Court decision, finding that the bright-line physical presence test articulated in Bellas Hess was preferable and invited the U.S. Congress to consider whether states should have the ability to require e-mailers to collect and submit sales and use taxes from purchases to their respective state residents.

In reversing the North Dakota Supreme Court, the U.S. Supreme Court distinguished between Due Process and the Dormant Commerce Clause requirements. Under Due Process there must be "some definite link, some minimum connection, between a state and the person, property or transaction it seeks to tax". In addition, the income attributed to the tax "must be rationally related to 'values connected with the taxing State". As such, a physical presence is not required for purposes of due process [15].

In material contrast, the Commerce Clause disallows state actions that unduly inhibit interstate commerce [17]. In other words, Due Process is focused on fairness for the individual defendant while the Commerce Clause focuses on the structural concerns and impact of state taxes on interstate commerce [15]. While the judicial interpretation of the Commerce Clause has evolved, it currently uses the four-pronged test articulated in Complete Auto Transit Inc. v. Brady to assess the validity of state taxes under the Commerce Clause [18]. Under the four-prong test, a state tax will be upheld under the Commerce Clause if it "(1) is applied to an activity with a substantial nexus with the taxing State, (2) is fairly apportioned, (3) does not discriminate against interstate commerce, and (4) is fairly related to the services provided by the State" [15]. The focus of the second and third prong is to ensure state taxes are not unfairly restraining interstate commerce by requiring fair apportionment and non-discrimination. The first and fourth prong requires a substantial nexus between the tax and services provided by the state. Under Bellas Hess the first prong was interpreted to stand for the proposition that a seller lacks the requisite substantial nexus if the only contacts with the taxing State are by mail or common carrier. Based upon the distinct purposes and tests, "the "substantial-nexus" requirement is not, like 
due process' "minimum-contacts" requirement, a proxy for notice, but rather a means for limiting state burdens on interstate commerce" [15].

Based upon the distinction, the U.S. Supreme Court held that the North Dakota Supreme Court commingled the issue and held that physical presence was not a requisite of the Commerce Clause. While physical presence is not necessary for Due Process, the U.S. Supreme Court elected to uphold the physical presence requirement in Bellas Hess, thus overruling the North Dakota Supreme Court. In its holding, the U.S Supreme Court acknowledged its uncertainty with the approach but elected to maintain a bright line rule for consistency purposes. Additionally, the Court seemed to encourage Congress to take up the issue as to the state's authority [15]. Interestingly, three of the justices concurred with the opinion solely on the grounds of stare decisis.

Direct Marketing Association v. Brohl: Another effort designed to permit collection of sales and use taxes on outof-state electronic transactions was considered in Direct Marketing Association v. Brohl [19]. As held in Quill, states are unable to impose taxes directly on e-tailers unless they have a physical presence in the state. The states, however are free to impose sales taxes on its residents and use taxes on nonresidents who keep the property within the state's borders. Unfortunately, there is significant noncompliance associated with the voluntary reporting system. For example, Colorado estimates that $25 \%$ of internet sales into the state escape taxes with loss revenue from internet sales increasing by $\$ 20$ million each year. In 2012, Colorado claimed that the losses were about $\$ 170$ million [19].

In order to increase compliance, Colorado passed the Tax Injunction Act (TIA) which requires e-tailers with gross sales in Colorado exceeding $\$ 100,000$ to report certain information. The reporting obligations require the e-tailer to provide the names of Colorado customers, addresses, and total amount of purchases during the preceding calendar year. Failure to provide the information filing was subject to a $\$ 10$ penalty per-customer for each person who should have been included within the filing. In addition to the informational filing, the seller was responsible for providing certain information to the buyer. The additional requirements include notifying Colorado purchasers prior to each transaction that the buyer is responsible for sale or use taxes on certain purchases. Failure to provide this notice could result in a $\$ 5$ fine per violation. In addition, sellers were required to mail a notice to Colorado purchasers who bought more than $\$ 500$ worth of goods during the prior year. The mailing was required to contain information relating to the dates, categories, and amount of those purchases. The notice was also required to notify the buyer of their responsibility to pay the sale or use taxes on the purchase. Failure to abide by this provision could results in a $\$ 10$ penalty per infraction. Direct Marketing Association challenged the requirements claiming a violation on the Dormant Commerce Clause.
The District Court ruled in Direct Marketing Association's favor. Colorado appealed based upon the procedural issue relating to the Tax Injunction Act, questioning whether the Court had the authority to prohibit the tax. The issue before the U.S. Supreme Court was whether the Tax Injunction Act prohibits federal district courts from enjoining, suspending, or restraining the assessment, levy, or collection of tax under State law, as the TIA mandates. The U.S. Supreme Court held that the Act did not prohibit the district court from hearing the issue. While the merits of the case were not before the Court, Justice Kennedy wrote a concurring opinion relating to the Dormant Commerce Clause [19].

In Justice Kennedy's concurrence, he elaborated on Quill, concluding the Quill holding should be revisited. Kennedy acknowledged that even at the time of the Quill holding, the majority recognized the result may be incorrect. What made Kennedy's holding even more interesting is that he was part of the majority decision on the Quill case, and now indicates that the case should be revisited. In addition, Justice Kennedy points out that three of the justices focused their votes exclusively on the grounds of stare decisis [19].

At the time of the Quill holding, however, e-commerce was in its infancy stage, with mail-order sales totaling $\$ 180$ billion [15]. In today's market, e-commerce has transformed the way consumers purchase items. In 2011, approximately $70 \%$ of consumers purchased items online with e-commerce sales totaling \$3.16 trillion annually [19]. Based upon the Quill holding, states have been substantially thwarted in collecting taxes on these sales. While the buyer is responsible for reporting and remitting sales or use taxes on the purchase, the practical constraints of identifying and collecting the taxes has been administratively impractical. For example, California believes it only collects about $4 \%$ of these taxes [19].

South Dakota v. Wayfair: Based upon the encouraging signals in Direct Marketing Association v. Brohl from some justices on the U.S. Supreme Court, the South Dakota legislature developed and enacted Bill 106, a law similar to the North Dakota statute that was previously found impermissible in Quill. The State of South Dakota is well positioned to challenge the continued prohibition, both in terms of economic harm and the structure of the law. From an economic perspective, South Dakota is one of seven states without a state income tax. Instead, South Dakota relies upon its sales tax to help generate sufficient income to offer governmental services. Based upon the holding in Quill, South Dakota is losing significant income through e-commerce transactions.

In addition to the economic harm, the state legislature carefully crafted a bill designed to require qualifying out-ofstate retailers lacking the physical presence in South Dakota to collect and remit sales taxes to the State of South Dakota [20]. The law applies to sellers who either transact over $\$ 100,000$ in gross sales during the calendar year or engages 
in at least 200 separate transactions during a calendar year [20]. The applicable exclusion ensures that smaller e-tailers with minimal contacts to the state are not disproportionately impacted by the enhanced procedural requirements. Sellers who failed to collect and remit sales taxes are subject to a declaratory judgment action. It is also important to note that the Act prohibits retroactive application of the duty to collect, ensuring the obligation to collect is only applied to sales after the date of the Act, and that initiation of proceedings serve as an automatic stay from the state's continued collection efforts [21].

Following enactment of Bill 106, qualifying businesses were sent notices informing them of their obligation to register for a South Dakota sales tax license and well as the penalty for failure to comply with the statute [21]. Four companies, including Wayfair, refused to comply with the new statute. As such, the State filed a declaratory judgment action against the sellers. The State sought a judicial declaration that the requirements of Senate Bill 106 were valid and applicable to Sellers. The sellers countered by having the case removed from federal court based upon the issue of a federal question. The case was appropriately moved to the South Dakota circuit court. Once removed to circuit court, the sellers moved for summary judgment contesting the constitutionality of the statute. The state agreed that the court would have to grant the motion, while stating it would pursue the question to the U.S. Supreme Court [21]. The U.S. Supreme Court has agreed to hear the case, presenting it with the long-awaited opportunity to revisit the Quill holding. A decision is expected to be released during the summer of 2018.

\section{Legislative Measures}

The U.S. Supreme Court has acknowledged that the U.S. Congress is positioned to regulate interstate commerce. If the elected officials choose to do so, they possess the authority to intervene by modifying regulations [15]. In other words, the U.S. legislature has the authority to permit states to impose a tax collection burden on out-of-state e-tailers lacking a physical presence within their state boundary, for sales to consumers who are present within the state boundary when making the purchase. While the legislative branch has not passed legislation providing states with the authority to impose sales taxes on these out-of-state sellers, they are currently considering the Remote Transactions Parity Act [22].

The Remote Transparency Act was introduced in the U.S. House of Representative on April 27, 2017. The bill would permit each state that is a member under the Streamlined Sales and Use Tax Agreement (the multistate agreement for the administration and collection of sales and use taxes adopted on November 12, 2002) to mandate that out-of-state sellers collect and remit sales taxes on sales to their residents [23]. The Act, similar to South Dakota's new bill, contains exclusion for smaller businesses. More specifically, the collection mandate would only apply to remote sellers that have "gross annual receipts exceeding specified amounts, which are phased in from $\$ 10$ million for the first year following the effective date, to $\$ 5$ million for the second year, and \$1 million for the third year; or (2) utilizes an electronic marketplace for the purpose of making products or services available for sale to the public" [22]. Interestingly, the bill was introduced by Congresswoman Kristi L. Noem, a U.S. Representative from South Dakota which is the same state which developed the law challenging the inability of states to mandate collection of sales taxes on out-of-state retailers.

While Congress is currently considering action to permit the collection of state income taxes for out-of-state purchases, it must be noted that introduction of bills designed to address the issue have previously been considered over the past decade [23]. The earlier proposed bills, however, failed to materialize leaving states powerless to collect taxes on outof-state purchases through remote sellers.

\section{Analysis}

The limitations currently imposed on a state's ability to require the collection and remission of state sales and use taxes imposed on out-of-state e-tailers may soon be overturned. The emergence of technology has transformed the way business is conducted as well as the resources that are used. The U.S. Supreme Court issued its original physical presence mandate in its 1967 decision in Bellas Hess. During that time E-commerce was an unsubstantial component of total sales. The U.S. Supreme Court revisited the physical presence requirement twenty years later and acknowledges that Dormant Commerce Clause jurisprudence has evolved and that E-commerce and technological advances were emerging but kept the physical presence requirement based upon stare decisis and the preference for a bright line rule.

Based upon the opinions relating to the Dormant Commerce Clause issued in 2015, five justices expressed their objection to expanding the Dormant Commerce Clause. More specifically, Justice Kennedy indicated that the Quill decision should be revisited. Additionally, Justices Scalia and Thomas expressed their strong discontent with the Dormant Commerce Clause. Even at the time of the Quill holding, the majority was not sure the decision was correct. While the U.S. Supreme Court distinguished between the requirements under Due Process and the Dormant Commerce Clause it refused to overrule the physical presence requirement, instead inviting Congress to revisit the issue [19]. Moreover, the Court agreed with the North Dakota Supreme Court in terms of the evolution of the Commerce Clause decision whereby the Court favored a more flexible balancing analysis. The U.S. Supreme Court, however, felt the benefit of providing a bright line test was important for terms of establishing requirements under the Dormant Commerce Clause [19]. It is important to note, however, that E-commerce was still in its infancy stage at the time of the Quill holding.

While the bright line rule has provided guidance, the 
volume of internet sales has placed heightened demand on states as out-of-state vendors still rely on limited state resources such as availing themselves to the state courts for protection as it relates to creditor rights. Moreover, advertisement from online e-tailers has continued to develop. In Quill, the only contacts within the state were the advertisements in a national publication and occasional solicitation through a phone call. The methods of marketing as an e-tailer have substantially changed. Organizations are now able to provide integrated websites indistinguishable from in state organizations.

Even if the U.S. Supreme Court finds in favor of Wayfair based upon the concept of state decisis, Congress has continued to advance efforts affording states more leverage in terms of imposing duties on sellers to collect and remit state sales taxes. While Congress has been unsuccessful in passing the bills that have been introduced, the continuous introduction of revised bills reflects some degree of legislative interest in providing states a degree of freedom in imposing the duty of collection.

If states are successful, either through judicial or legislative means, e-tailers will need to consider different pricing strategies to remain competitive with residential sellers. Due to the diminution in information asymmetries, more e-retailers are implementing a cost leadership strategy, whereby they are competing based upon price [5]. The competitive advantage afforded to the e-tailer by not requiring the collection of state and use taxes has allowed e-tailers to develop a low-cost leadership strategy. Traditionally, the competitive environment was conducive to a cost leadership strategy, as e-commerce advancements are beginning to mirror the concept of a perfect market. As a result, competition has intensified based on cost leadership, resulting in lower profit margins [5]. The cost leadership strategy is popular as e-retailers often possess significantly reduced transactional costs as compared to a brick and mortar business. This follows from the fact that the Internet market is likely to have less friction resulting from a reduction in transaction [6]. Specifically, consumers may be price sensitive on the internet, in part, because of the reduction in search costs [7]. Moreover, the consumer can easily and expeditiously ascertain the price of competitors for the same product. The competitive advantage is a substantial impediment for in state sellers subject to the collection requirements of state and use taxes.

The perceived increase in prices will make it more challenging for e-tailers to compete based upon price in states that have a sales tax. Even though the imposition of a duty on the collection and remission of state sales taxes may diminish the availability of a cost leadership strategy, it does not mean e-tailers will be unable to continue to use the strategy, as it only stands for the proposition of the appearance of an equitable price in terms of taxes. More specifically, e-tailers may still enjoy a cost leadership strategy in terms of traditional measures such as reduced costs and economies of scale.

\section{Conclusion and Discussions}

As e-commerce continues to reinvent the business landscape, the regulatory environment will continue to evolve. Over the past half-century, many nonresident retailers have been able to advance their business models without the added responsibility of collecting state sales taxes on transactions. While the current law does not excuse the customer from the obligation of remitting sales or use taxes on the purchase, it shifts the responsibility from the seller to the consumer. The shifting of the burden, however, has frustrated the ability of the state to collect state taxes. The State of California estimates a compliance rate of four percent on out of state purchases [4]. To mitigate the lost revenue, states have attempted various methods, to no avail, in order to require of state retailers to collect sales or use taxes on transactions entered into with customers within the state.

The prevalence of online sales is associated with the level of state taxes that must be collected by the retailer on the transaction. Studies have shown that an increase in state taxes will decrease the level of online sales [11]. Under the current tax structure, nonresident retailers with minimal contacts within the state are able to escape the tax collection responsibility. This is important as nonresident e-tailers are able to capitalize on the appearance of being the cost leader within the industry. When considering the high amount of state and local taxes in many states, the sales price may appear to be significantly lower when purchased from a nonresident business. For example, the combined state and local sales taxes in Louisiana is slightly above 10 percent [24]. As such, a nonresident e-tailer with minimal contacts in Louisiana could capitalize on the appearance of selling the product to a Louisiana resident for ten percent less than a Louisiana based business, while still maintaining the same margin as the Louisiana based business. Moreover, the administrative barriers associated with identifying and collecting taxes for online purchases makes it substantially likely that sales or use taxes will not be collected on the transaction.

Based upon a favorable judicial interpretation of the law, online e-tailers are better positioned to be observed as the low-cost-leaders within their industry. The strategy, however, may be short lived. While the inability of states to tax nonresident retailers has been a hotly debated topic in both the legislative and judicial branches, recent dicta in Direct Marketing Association v. Brohl have signaled a potential change [19]. Based upon the favorable comments, the State of South Dakota developed a law that requires most nonresident e-tailers to collect state sales taxes. The law is currently being challenged in South Dakota v. Wayfair [21], which will be heard by the U.S. Supreme Court during the 2018 session. In addition, the U.S. Congress continues to explore different mechanisms to allow states to tax e-tailers. The judicial and legislative action is making it more likely that the current tax structure will eventually be changed allowing states to tax these transactions. As such, e-tailers need to 
start reconsidering their position to determine whether a cost leadership strategy is sustainable even after collecting state sales taxes. If not, these businesses will need to evaluate their strategic position to avoid being "stuck in the middle".

The current study is based on previous research indicating that consumers focus on the listed price, and that an increase in the amount of taxes will decrease the number of online sales [11]. In addition, it is recognized that many online purchases are never reported by the consumer, thus resulting in these transactions escaping sales and use taxes [4]. Future research should explore the nexus between online purchases and nonreporting of the purchases to the state taxing authority. More specifically, future research should address whether the lack of reporting is intentional or if it is a misunderstanding of tax policies. This is important as it will provide insight into consumer purchases and help determine whether consumers are cognizant as to the source of the price differential and whether states should invest in an advertising campaign to educate consumers as to their responsibility for reporting and remitting taxes for online purchases.

\section{References}

1. eMarketer 2013. Available at: http://www.emarketer. com/Article/Ecommerce-Sales-Topped-1-Trillion-FirstTime-2012/1009649.

2. Horrigan, G. 2008. Retrieved from http://www. pewinternet.org/2008/02/13/online-shopping/.

3. Business Intelligence. 2017. Accessed on April 14, 2018 from http:/www.businessinsider.com/amazon-accountsfor-43-of-us-online-retail-sales-2017-2.

4. California State Board of Equalization, Revenue Estimate: Electronic Commerce and Mail Order Sales, Rev. 8/13, P.7, 2013.

5. Choi DH, Kim CM, Kim SI et al. Customer Loyalty and Disloyalty in Internet Retail Stores: Its Antecedents and its Effect on Customer Price Sensitivity. International Journal of Management. 23(4): 925.

6. Bailey, JP Faraj, S \& Yuliang, Y. 'The Road More Traveled: Web Traffic and Price Competition in Internet Retailing'. Electron Mark. 2007; 17(1).

7. Baye, MR Morgan, J \& Scholten, P. 'Information, Search, and Price Dispersion', in T. J. Hendershott (ed.) Handbook on Economics and Information Systems. 2006. Amsterdam. Elsevier.
8. Porter, ME. Competitive advantage: Creating and sustaining superior performance. New York: Free Press u.a. 1985.

9. Allen, RS \& Helms, MM. Linking strategic practices and organizational performance to Porter's generic strategies. Bus Process Manag J. 2006; 12(4):433-454.

10. Yang, J \& Aquilino, F. The Updated Status of Internet Commerce Tax Law. J Internet L. 2016; 20(2).

11. Einav, L Knoepfle, D \& Levin, J et al. Sales taxes and internet commerce. Am Econ Rev. 2014; 104(1):1-26.

12. Goolsbee, A. In a World without Borders: The Impact of Taxes on Internet Commerce. Q J Econ. 2000; 115: 561576.

13. Alm, J \& Melnik, MI. Sales Taxes and the Decision to Purchase Online. Public Finance Rev. 2005; 33(2):184212.

14. National Bellas Hess v. Department of Revenue of Illinois, 386 U.S. 753. 1967.

15. Quill Corporation v. North Dakota, 504 U.S. 298, 302.1987.

16. ND. Admin. Code §81-04.1-01-03.1, 1988.

17. South Carolina State Highway Dept. v. Barnwell Bros., Inc., 303 U. S. 177, 185. 1938.

18. Complete Auto Transit Inc. v. Brady, 430 U.S. 274. 1977.

19. Direct Marketing Association v. Brohl, 135 S. Ct. 1124. 2016.

20. SB 106, 2016. Legis Assemb, $91^{\text {st }}$ Sess $\S 1$ (SD 2016).

21. South Dakota v. Wayfair, Inc., 229 F.Supp.3d 1026. 2017. cert. granted (January 12, 2018) (No. 17-494).

22. Remote Transactions Parity Act-H.R.2193-115th Congress (2017-2018) retrieved at https://www.congress. gov/bill/115th-congress/house-bill/2193.

23. Brief South Dakota v. Wayfair, et al. as Amici Curiae United States Senators Ted Cruz, Steve Daines, and Mike Lee, 4 Apr. 2018, www.supremecourt.gov/ DocketPDF/17/17494/42397/20180404175941156_ Wayfair\%20Amicus-US\%20Senators.pdf .

24. Walczak J \& Drenkard S. State and Local Sales Tax Rates 2018 Fiscal Fact. Tax Foundation 2018. No. 572. Retrieved from https:/files.taxfoundation.org/20180313143458/ Tax-Foundation-FF572.pdf.

\section{*Correspondence to:}

Brian Winrow

Department of Accounting, Winona State University,

Minnesota

United States

Tel: 507-457-5172

E-mail: bwinrow@winona.edu 